\title{
Multidimensional assessment of sustainability extractivism of mangrove oyster Crassostrea spp. in the estuary of Cananéia, São Paulo, Brazil
}

\author{
Machado, IC. ${ }^{a *}$, Fagundes, L. $^{a}$ and Henriques, MB. ${ }^{a}$ \\ ${ }^{a}$ Instituto de Pesca, Secretaria da Agricultura e Abastecimento do Estado de São Paulo, \\ Avenida Bartolomeu de Gusmão, 192, CEP 11030-906, Santos, SP, Brazil \\ *e-mail: imachado@pesca.sp.gov.br
}

Received: November 7, 2013 - Accepted: 6 March, 2014 - Distributed: August 31, 2015

(With 11 figures)

\begin{abstract}
This study was carried out with groups of extractivists of mangrove oysters in the estuary of Cananéia, São Paulo State, Brazil, between the years 1999 and 2007 with the objective to evaluate and compare trends in the sustainability of this activity, in a multidimensional and integrated way, in social, economic, ecological, technological and ethical dimensions, using the method RAPFISH. The different groups had distinct trends related to sustainability and the social, technological and ethical dimensions had more influence on trends in sustainability than the ecological and economic dimensions. The group with the best performance in the sustainability assessment was Mandira, due to advances promoted by local social organization. On the other hand, the Porto Cubatão group showed the worst performance, once this is very recent group in the extractivism of oysters. The RAPFISH proved to be a useful tool for data assessment.
\end{abstract}

Keywords: sustainability, Crassostrea spp., mangrove oyster, extractivism, fishery.

\section{Avaliação Multidimensional de sustentabilidade do extrativismo da ostra de mangue Crassostrea spp. no estuário de Cananéia, São Paulo, Brasil}

\begin{abstract}
Resumo
O presente trabalho foi desenvolvido junto aos grupos de extrativistas de ostra em Cananéia, SP, entre os anos de 1999 e 2007 e teve o objetivo de avaliar e comparar as tendências relativas à sustentabilidade dessa atividade, de forma multidimensional e integrada, nas dimensões social, econômica, ecológica, tecnológica e ética, utilizando o método RAPFISH. Os diferentes grupos estudados apresentaram dististas tendências relativas à sustentabilidade e as dimensões social, tecnológica e ética exerceram maior influência sobre as tendências da sustentabilidade, do que as dimensões ecológica e econômica. $\mathrm{O}$ grupo com melhor desempenho na avaliação de sustentabilidade foi o do Mandira, em razão dos avanços promovidos pela organização social local, no extremo oposto posicionou-se o grupo do Porto Cubatão, em razão do grupo ser muito recente no extrativismo de ostras. O Rapfish se mostrou uma ferramenta útil no equacionamento dos dados.
\end{abstract}

Palavras-chave: sustentabilidade, Crassostrea spp., ostra de mangue, extrativismo, pesca.

\section{Introduction}

In one major contemporary events on environmental issues, at the United Nations Conference on Human Environment (held in Stockholm, in 1972), the idea that environmental policies should not impede social and economic development was emphasized. The Brundtland Report Our Common Future (written by the World Commission on Environment and Development - WCED, in 1987) introduced the concept of sustainable development such as "the use of natural resources without compromising the ability of future generations to satisfy their needs" and the United Nations Conference II on Environment and Development (Rio de Janeiro, in 1992) consolidated the concept of sustainable development as the main guide of current environmental approach. Marrul Filho (2001) believes that this concept enabled the environmental legitimacy of the market economy. On the other hand, Salamoni and Gerardi (2001) stated that this concept showed the need to satisfy social and productive needs to allow sustainability. Several authors, with varying approaches, have discussed the concept of sustainability in this historical context. The World Conservation Strategy, cited by Feeny et al. (1990), defines sustainability as the successful management of resources, without necessarily implying in ecological or economic success. 
The International Society for Ecological Economics, cited by Salamoni and Gerardi (2001), defines sustainability as a relation between dynamic, ecological and economic systems, guided by the evolution of human life, crop development and control of anthropic effects to ensure that they do not threaten diversity.

Some studies have reported the failure of conventional methods to assess and manage natural resources to promote sustainability, attributing the failure to the fragmented and linear approach, based only on quantitative biological data. Recent research on production sustainability of natural resources point to a more holistic and comprehensive approach to their assessment and management, underscoring broader aspects of ecological and economic issues (Larkin, 1977; Charles, 2001; Berkes et al., 2001; Berkes et al., 2003).

The mangrove oyster, Crassostrea spp. extracted from the estuary of Cananéia, São Paulo State, Brazil, began to be marketed locally in the 1950s, and from the late 1970s onwards, it became an important alternative for subsistence extractivists in the region (Santos et al., 2009).

In 1995, an inter-institutional project introduced the "fattening" of oysters to the communities of Cananéia (Maldonado, 1999; Pereira et al., 2001; Medeiros, 2004; Garcia, 2005). This management method is economically and environmentally important as it aggregates market value to the oysters, which spawn in the fattening farms, allowing natural replenishments of stocks (Galvão et al., 2000). Henriques et al. (2010) reported that about $40 \%$ of the oyster production in Cananéia originated from fattening farms.

According to Mendonça (2007), in the past ten years, the oyster has been the main product in small-scale fishery of Cananéia. Although their contribution is small compared to total fish trades, oysters are some of the main products of the estuarine area in the municipality of Cananéia, benefiting directly about a hundred families (Machado, 2009; Machado et al., 2010). The present study aimed to evaluate and compare sustainability trends for the extractivism of mangrove oyster, practiced by different fisher groups in the Cananéia Estuary, São Paulo State, Brazil. We identified factors that affect the activity, which were analyzed in a multidimensional and integrated way in terms of social, economic, ecological, ethical and technological aspects.

\section{Material and Methods}

The definition of sustainability criteria was obtained from aspects studied between 1999 and 2007 in the following studies: socioeconomic (Machado et al., 2010), economic (Machado, et al. in press), monitoring of production (Mendonça and Machado, 2010), assessment of stocks in natural oyster banks of extractivism areas (Pereira et al., 2000; Pereira et al. 2001; Henriques et al., 2010) and ethnoecology of extractivists from the Cananéia Estuary (Santos et al., 2009; Machado et al., 2011).

The extractivists were divided into groups according to the location of their residences and the areas where they harvest oysters.
The sustainability of mangrove oyster extractivism practiced by various groups was evaluated and compared using the RAPFISH method (Pitcher, 1999;Alder et al., 2000; Pitcher and Preikshot, 2001). RAPFISH consists of a multivariate statistical method for multidisciplinary evaluation of sustainability between comparative fishery activities, from a predefined set of criteria grouped into five dimensions: ecological, economic, technological, social and ethical. The criteria are scored and submitted to statistical ordering MDS (Multi-Dimensional Scaling) from references that include the "best" and "worst" status of sustainability (Pitcher and Preikshot, 2001).

\subsection{Extractivist groups and their areas of extractivism}

Nearly a hundred extractivists extract oysters from the mangroves of Cananéia, and the majority is men, between 30 and 50 years of age, married, with low income and low formal education (Machado, 2009). Six groups of extractivists were identified based on the location of their residences and the areas where they harvest the oysters: Sítios, Acaraú, Itapitangui, São Paulo Bagre, Porto Cubatão and Mandira.

The areas used for oyster extractivism extend along the main channel, rivers and "gamboas" (internal channels of the estuary) of the Cananéia Estuary, up to approximately the middle part Ararapira Canal.

With the exception of the Extractive Reserve of Mandira, which is managed exclusively by a group under the same name, all other fields are freely accessible. There are no regulations regarding their use, which is dictated by the habit to frequent the area, logistic aspects and abundance of oysters (Santos et al., 2009).

It was designated as belonging to "Sítios", 23 extractivists that resided in fishing sites with exclusive access by waterway, located on the continental margin of the Ararapira Canal: Ilha da Casca, Retiro, Bombicho and Itapanhoapina. In 2007, extractivists from "Sítios" harvested oysters in an area that stretched from the municipality of Retiro to the municipality of Marujá, on Ilha do Cardoso.

The fifteen extractivists from the Acaraú region reside in this neighborhood and own houses or fishing places in the municipalities of Itajuba, Taquari, Cantagalo and Guapara, or in the villages of Bica and Prainha. In 2007, the extractivists from Acaraú acted from the Taquari to the Tumba River.

Porto Cubatão comprises the largest continental neighborhood of Cananéia on the shores of Cubatão Sea. In 2007, the 13 extractivists from this group acted from the Aroeira Bridge to Sítio Torrado, in the municipality of Barra do Rio Itapitangui.

Itapitangui is another continental neighborhood of the municipality and makes the transition between the urban and rural areas. Its 13 extractivists, in 2007, exercised the activity throughout the Itapitangui River to the Taquari River.

The neighborhood São Paulo Bagre is located on the Cananéia Island, along the shore of the Cananéia Sea. Oyster extractivism is incipient in the community, adopted 
by only four people. In 2007, the extractivists from São Paulo Bagre extracted oysters from the Aroeira Bridge as far as the Boguaçú River, on the westside of Ilha Comprida.

Mandira neighborhood is located on the mainland, near km 11.5 of Itapitangui-Ariri Road. With 29 local extractivists, this community may be considered a specialist in oyster production. In 2007, the extractivists from Mandira acted exclusively in the area of Extractive Reserve of Mandira.

\subsection{Sustainability assessment}

The criteria used for the sustainability assessment of mangrove oyster extractivism are listed in Table 1. The criteria prescribed by the matrix of the RAPFISH

Table 1. Criteria for the sustainability assessment using the RAPFISH method.

\section{Ecological Criteria}

Status of the resource exploration: we crossed data obtained from the status of oyster stock in the area explored by the group and analyzed whether or not there was use overlapping of groups in the area.

Group that explores the area of good oyster stock, without overlapping with other groups (0); group that explores the area of good oyster stock, overlapping with other groups (1); group that explores mixed areas, overlapping with other groups (2); group that explores the area of critical stock, without overlapping with other groups (3); group that explores the area of critical stock, overlapping with other groups (4).

Evidence of resources reduction in the area explored by the group: we crossed data obtained from the area with parcels that indicate depletion of oysters in the stock assessment.

None (0); Some (1); Many (2).

Loss for lack of criterion at extractivism: losses due to sales procedures.

Low (0); Medium (1); High (2).

\section{Percentage of oyster extractivists that use fattening technique:}

Above $70 \%$ of extractivists using fattening technique (0); 50-70\% of extractivists using fattening technique (1); less than $50 \%$ of extractivists using fattening technique (2).

Percentage of the annual production of the group managed in fattening farmers:

Very high, above $80 \%(0)$; high, between 50 and $80 \%$ (1); average, between 30 and 50\% (2); low, below $30 \%$ (3).

\section{Economic Criteria}

Price: analyzed between the extractivism procedure and sales opportunities

Great (0); Good (1); Reasonable (2); Bad (3); Terrible (4).

Subsidies: Are there subsidies along the supply chain of the activity?

None (2); Some (1); Several (0).

\section{Average salary:}

Above 50\% with remuneration greater than $3 \mathrm{SM}^{*}$ (4); at least $30 \%$ with remuneration greater than $3 \mathrm{SM}(3)$; at least $30 \%$ with remuneration greater than $2 \mathrm{SM}(2)$; at least 50 with remuneration greater than $1 \mathrm{SM}$ (1); above $50 \%$ with remuneration up to $1 \mathrm{SM}(0)$.

\section{Access to perform the activity:}

Free access (0); Little or informal control (1); Medium control (2); Strong control (3); Strictly limited (4).

Autonomy and empowerment to market the product: Items that give security to the producer in the continuity of the activity (access to buyer, regularity of sales, influence on price formation)

Good (2); Medium (1); Bad (0).

Other income sources: Maximum 20\% of the individuals in the group without other income sources and at least six income alternatives in the group (0); from 20 to 40 individuals with no other income sources and at least six alternatives (1); up to $40 \%$ without other income sources, with at least four alternatives (2); up to $40 \%$ without other income sources, with at least four alternatives (3).

\footnotetext{
*SM $=$ minimum wage in Brazil, in effect in the year of study (2007) corresponding to R \$380.00 (circa US\$192.00).
} 
Table 1. Continued...

\section{Economic Criteria}

Profit in the activity: Relates to sales opportunities.

Entractivism profit is predominantly managed by the group (0); shared (1); or it is performed by external sales agents (2).

Market characterization: The market is mainly local/national (0); national/regional (1); international (2).

\section{Social Criteria}

Socialization of the activity: Individual extractivism - oyster is not sold jointly or processed with the family (0), familiar - oyster is processed within the family, cooperate with each other in selling (1) or community - process and sell as a group; handle management problems, post-extractivism and selling jointly (2).

Admission of new extractivists in last years: admission in the last 10 years $<10 \%$ (0); 10-20\% (1); 20-30\% (2); >30\% (3).

Number of families with extractivists in the community:

Few - below 10\% (0); Some - from 10 to 30\% (1); Many - above 30\% (2).

Regularization and professional support: unemployment benefits, registration to Social Security, affiliations to representative entities, fishing authorization.

None (0); Some (1); Large (2).

Percentage of producers who have oyster extractivism as their main income source: main income source of as a factor in strengthening social identity. $\%$ of household income $<50 \%(0) ; 50-80 \%(1) ;>80 \%(2)$.

Influence of the oyster extractivist on management: Significant (0); Some (1); Almost none (2).

\section{Technological Criteria}

Oyster landing sites: logistics for commercialization

Dispersed (0); Little centralized (1); Highly centralized (2); Distant from vessels or inexistent (3).

Processing to add value: shelling, packaging, transportation, etc:

None (3); Minimum (2); Average (1); High (0).

Product storage in the fattening structures: fattening as a conservation strategy and production planning: Minimum (0); Little (1); High (2).

Side effects of the activity: regarding income source.

None (3); Some (2); High (1); Fishing marked by destructive practices (0).

\section{Ethical Criteria}

Proximity and dependence: geographical proximity and history connection.

No proximity or dependence (0); No proximity, some dependence (1); Proximity, some dependence (2);

Proximity, strong dependence (3).

Alternatives to the activity available to the group:

None (0); Some (1); Many (2).

Equity to admission to the activity: admission based on the historical and traditional access Non-considered (0); Considered (1); Traditional native fishing (2).

Participative management in resource use: inclusion of extractivists to management None (0); Consultation (1); Co-management with the government in charge (2); co-management with the community in charge (3); co-management with equal participation of parts (4).

*SM = minimum wage in Brazil, in effect in the year of study (2007) corresponding to R \$380.00 (circa US\$192.00). 
Table 1. Continued...

\section{Ethical Criteria}

Structures that may influence values: affiliation to entities may promote changes in behavior.

Highly negative (0); Somewhat negative (1); Neutral (2); Somewhat positive (3); Highly positive (4)

\section{Disposal and waste:}

None (4); Little (3); Medium (2); (1) Much; (0) Predominant.

\section{Illegal extractivism:}

None (4); Little (3); Medium (2); (1) Much; (0) Predominant.

*SM = minimum wage in Brazil, in effect in the year of study (2007) corresponding to R\$380.00 (circa US\$192.00).

method were eliminated when they did not apply, and other criteria considered relevant to the case were added. To optimize the performance of comparison, the criteria where scores between groups were completely homogeneous were disregarded. For example, we deleted the ecological criterion "captured species", which is coincidental in all groups studied.

\subsection{Results and discussion}

In 2007, the oyster production in Cananéia amounted to 189 thousand dozens. The groups of Sítios, Itapitangui and Mandira produced the largest volumes and the rate of extractivists that practiced the fattening oysters was expressive (64\%), denoting that the activity is well established in the region (Machado, 2009).

The ecological sustainability dimension showed the best performance for all the groups. Only two groups, Itapitangui and Porto Cubatão, had performance below $50 \%$, tending to unsustainability. The São Paulo Bagre and Mandira groups showed the best performance in terms of ecological sustainability (Figure 1).

Based on the stock assessment conducted in the estuary of Cananéia (Pereira et al. 2000; Pereira et al. 2001; Henriques et al., 2010), a rating of "good" was given to the stocks in the areas explored by extractivists from Mandira, Sítios and São Paulo Bagre; a rating of "low" to the areas explored by groups from Itapitangui and Porto Cubatão and "intermediate" to the areas explored by Acaraú groups. However, the criteria associated with the status of the extractivism areas had a secondary role in the evaluation of ecological sustainability.

The "Loss for lack of criterion in oyster extractivism" expresses the management practices that can lead to postharvest mortality rate and Porto Cubatão, Itapitangui and Mandira showed the greatest losses.

The most significant criteria for the assessment of ecological sustainability were associated with management choices: the percentage of the annual production of the group managed in fattening farmers and percentage of oyster extractivists that use fattening technique (Figure 2).

Regarding economic sustainability, we found that São Paulo Bagre, Itapitangui and Porto Cubatão showed values below $50 \%$, tending to unsustainability and the worst scenario was observed in Porto Cubatão. Mandira showed the best performance (Figure 3).

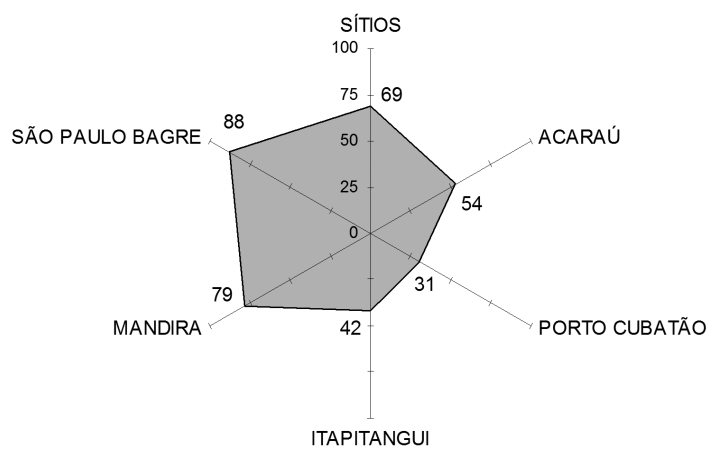

Figure 1. Analysis of the ecological sustainability dimension.

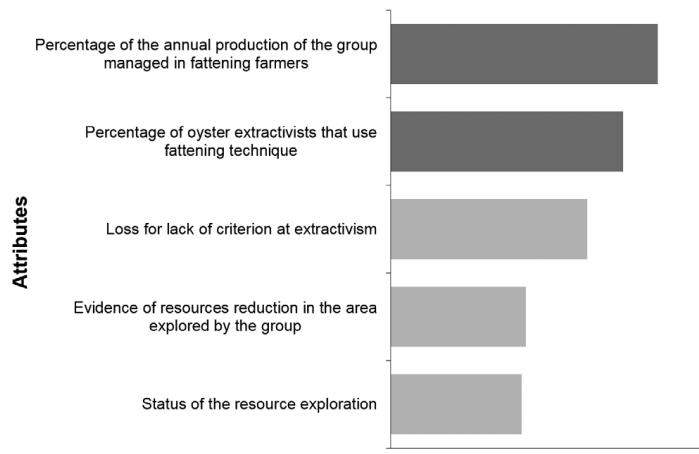

Figure 2. Influence of attributes on the ecological dimension.

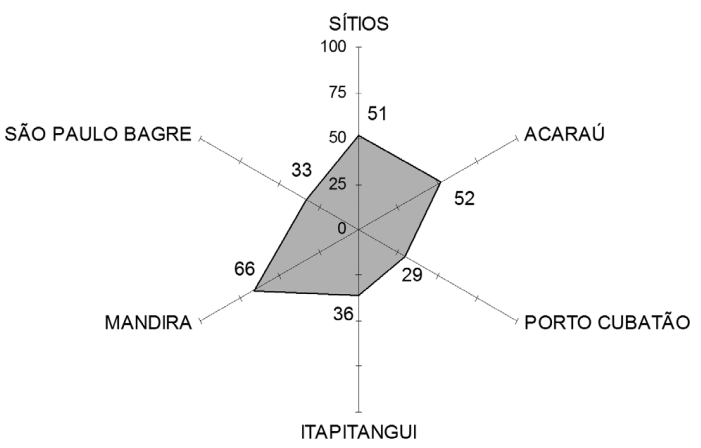

Figure 3. Sustainability analysis of economic dimension. 
The criterion that most affected the results of economic sustainability were the existence of limits to admission to the activity ("Access to perform the activity"), followed by the criteria of autonomy, security and regularity in trading the product and the existence of subsidies for the activity. The factors associated with extractivists remuneration, average salary, profit distribution and the product price showed no dominant influence on trends of economic sustainability (Figure 4).

Regarding the admission of new extractivists to the activity, Berkes (2005a) and Rebouças et al. (2006) report that, by allowing the exclusion of new resource users, property rights are key points to be taken into account in procedures for the resource management of commons, defined as the resources that show difficulty of excluding users and whose collective use cause subtraction and collapse (Feeny et al, 1990; Ostrom et al, 1994; Berkes, 2005a; Seixas and Berkes, 2005). The categories of resource property of commons can be combinations of free access, communal property, state-owned and private property (Feeny et al, 1990; Berkes, 2005a, b; Rebouças et al, 2006; Thé and Nordi, 2006). Berkes (2005a) states that the communal property can be effective to enable exclusion and control subtraction of inherent resources of commons. Among the groups of extractivists of Cananéia, only the group from the Extractive Reserve Mandira had exclusive right to explore its area (Brasil, 2002). Mandira was therefore the only group in which the category of resource property could be characterized as communal, which reflected in the sustainability analysis.

Regarding the commercial criteria, the Cananéia oyster is marketed in three different ways: "desmariscada" (raw oyster meat, chilled with ice), "in box" (live oysters in bulk, without selection by size) and "in dozens" (oysters, standardized by size). The first two ways show very low price to the producer (Machado, et al. in press) and were, in 2007, adopted primarily by groups from Itapitangui and Porto Cubatão. Sítios, Acaraú, and São Paulo Bagre sold exclusively as "oysters in dozens", whereas in Mandira, the three forms were practiced, with predominance for "in dozens".

Among the sales opportunities, Cooperostra Cooperative of Cananéia Oyster Producers - provided better remuneration to the producer. However, the entity assisted only the groups from Mandira, Sítios and Acaraú and the other groups sold oysters primarily to middlemen.

Regarding the social dimension, the groups from Mandira and Acaraú presented the best performances, as they did not present values below $50 \%$. Values below $50 \%$ show trends to social unsustainability (Figure 5).

The percentage of producers who have oyster extractivism as their main income source and the number of families with extractivists in the community were the criteria that showed the greatest influence on the analysis (Figure 6). Folke et al. (1998) highlight some principles for building resilience and promoting sustainability in socio-ecological systems, such as the construction of social mechanisms and the promotion of conditions for self-organization and institutional learning.

The larger number of extractivists who have oyster extractivism as main income source, as well as the high number of families with extractivists in the community, can influence sustainability in social dimension as they help to promote the social identity, which can result in the construction of social mechanisms and in the increase of the organization capacity of the group. The socialization of the activity, expressed through mechanisms for collaboration and partnerships, could also act in the same direction;

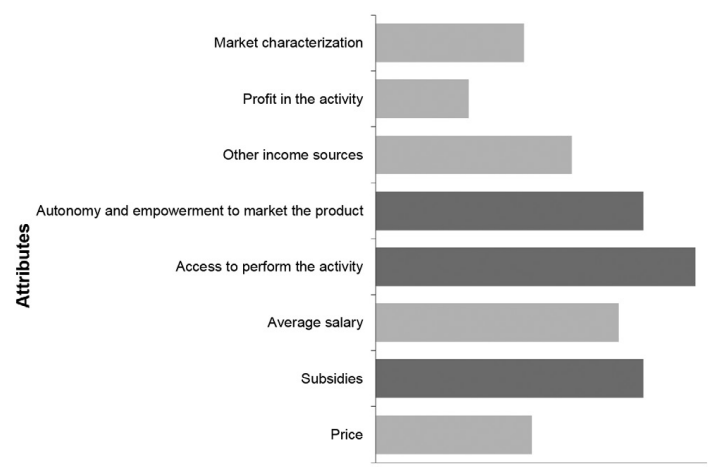

Figure 4. Influence of attributes on the economic dimension.

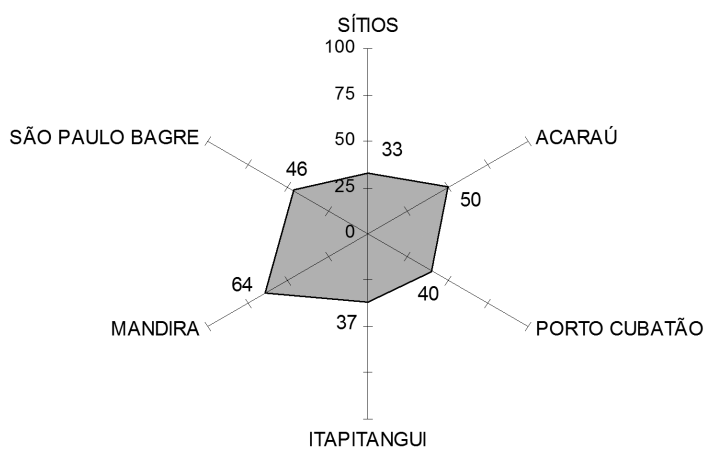

Figure 5. Sustainability analysis on the social dimension.

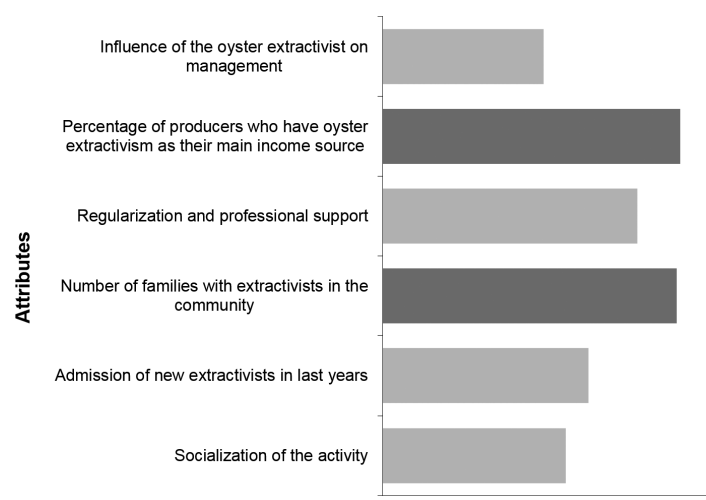

Figure 6. Influence of attributes on the social dimension. 
however, this criterion had poor influence on the analysis, as well as the influence of extractivists on management.

The criteria used to assess technological sustainability comprised the group organization for processing and marketing oysters; fattening practices and production of "desmariscada" and "in box" oyster (practices with negative side effects). Mandira had the best performance and Porto Cubatão had the worst rating (Figure 7) regarding the technological dimension. The criteria of greater influence on technological evaluation were the landing sites: logistics for marketing and pre-sale processing to add value to the product, through depuration, packaging and transport of oysters. (Figure 8).

In terms of ethical dimension, Mandira also had the best performance, followed by Sítios and Acaraú (Figure 9).

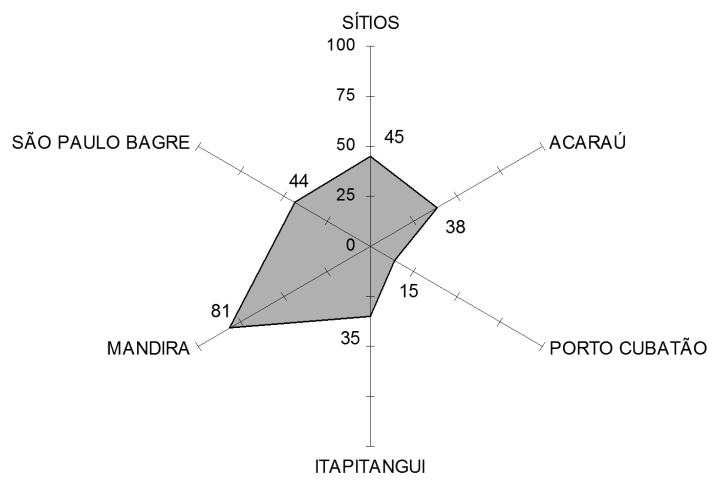

Figure 7. Sustainability analysis of technological dimension.

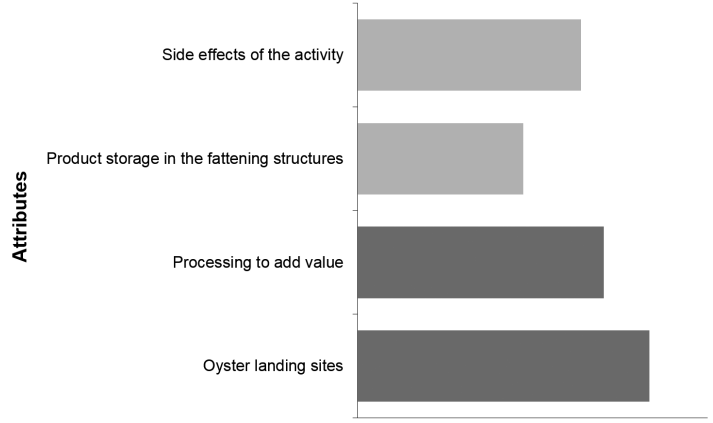

Figure 8. Influence of attributes on the technological dimension.

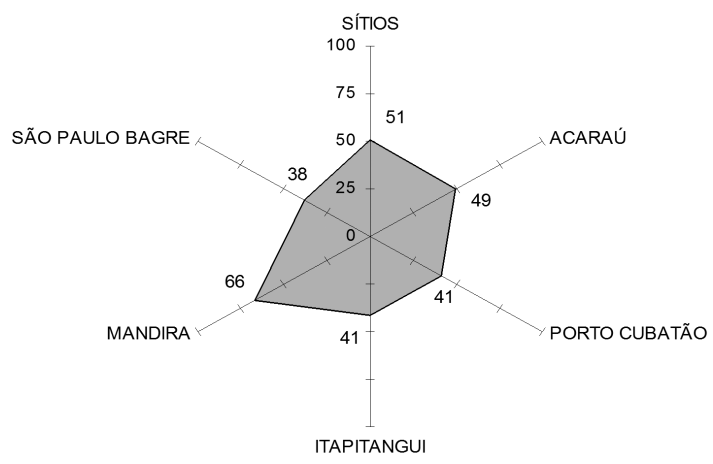

Figure 9. Sustainability analysis of the ethical dimension.
The criterion of greater influence on the ethical dimension of sustainability was the existence of a participative management process, followed by the equity for admission to the activity (Figure 10). At the time of the study (2007), the participative management process was only possible at the Extractive Reserve Mandira, where a formal council performed co-management. The equity for admission to the activity is associated with this criterion in the Mandira group, where there were rules described in the Plan of Use at the time; however, in Sítios and Acaraú, the equity was partially applied through informal territorial rules, which inhibited the action of outside extractivists in these groups and in their respective extractivism areas.

Figure 11 shows the consolidated results of the sustainability analysis of oyster extractivism in the RAPFISH method, showing that, in terms of group, Mandira had a greater trend to sustainability.

The advantageous circumstances that earned Mandira a better performance in the analysis are associated to the process of social organization that led to the recognition of its tradition and institutionalization of its extractivism area as a conservation unit of sustainable use (extractive reserve). This provided the system of communal ownership

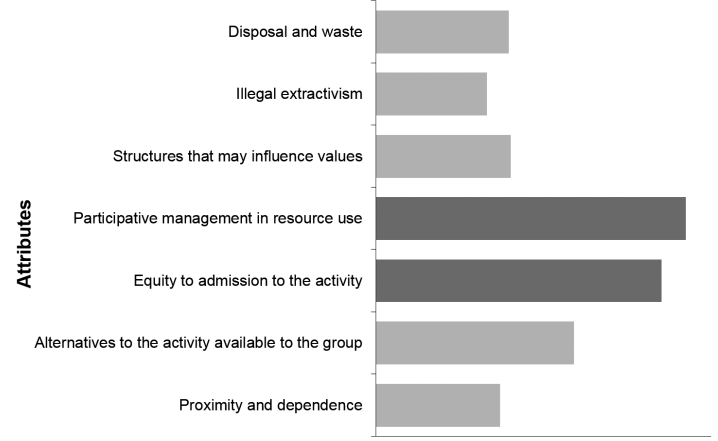

Figure 10. Influence of attributes on the ethical dimension.

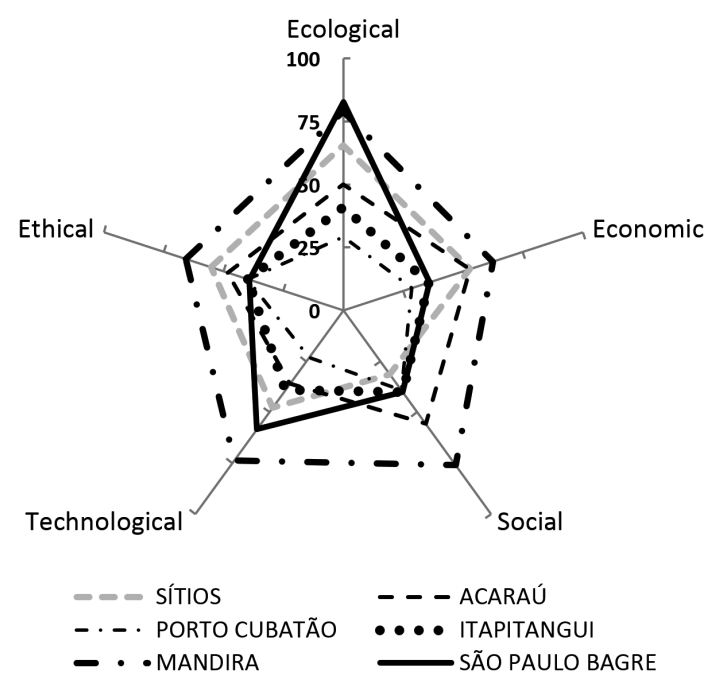

Figure 11. Consolidated analysis of sustainability using the RAPFISH method. 
of resources a limit for admission to the activity and construction of a commercial alternative socially fair.

These achievements were not exclusively a result of the community engagement, but they were made possible due to the various interventions applied, mainly from public institutions, by means of subsides and financial and technical investments, on which this community counted for a period of about 15 years (Garcia, 2005; Maldonado, 1999; Medeiros, 2004; Machado et al., 2011). These interventions can be considered as part of the social cost of promoting sustainability for the use of natural resources. In this sense, in assessing the performance of projects aimed at sustainability, the gains to be computed should consider all dimensions and not only the ecological and economical ones.

At the other end, the Porto Cubatão group presented the worst performance in nearly all dimensions studied. This is possibly a reflection of the increase of the group in the activity, with the greater part of the extractivists having joined the activity less than five years ago. Thus, besides not participating in the initiatives for production organization, which resulted in the creation of Cooperostra, extractivists of this group have not matured sufficiently in activity to enjoy collective or individual gains, being commercially and technologically very precarious.

For Porto Cubatão, as well as for the groups classified in the medium position, even if they attained sustainability in some specific dimensions, they presented themselves at relative risk, and unexpected changes may lead to a crisis.

Considering the big picture of sustainability of mangrove oyster extractivism in the estuary of Cananéia, the social, technological and ethical dimensions seem to have more critical influence on sustainability trends. Therefore, these dimensions should be considered as priorities in management actions. This result is consistent with findings of Jankowisky (2007), in the comparative assessment of sustainable extractivism of caranguejo-uçá Ucides cordatus in Cananéia.

According to Adrianto et al. (2005), the RAPFISH method promotes a sustainability assessment relatively static, "top-down" because it does not comprise all players involved. In addition, according to the authors, the criteria and scoring employed would be arbitrary. In our study, the use of the RAPFISH method provided an adequate consolidation of information obtained from the extractivists groups, showing that the multivariate analysis corresponds to the objective of thorough assessment of the activity. However, the method has limitations, and the most critical aspect is the fact that it reflects the surveyor's perception.

In view of that aspect and in agreement with the observations of Adrianto et al. (2005), the analysis was efficient for a preliminary comparison assessment of sustainability. An evaluation that is part of a management process should comprise the largest possible number of players, for the definition and scoring of criteria, favoring the presence of communities in the discussion. It demands an effort for the involvement and leveling of information, because there are discrepancies in the experience of the various extractivists groups regarding participatory management.

\section{Conclusions}

The different groups of extractivists from the estuary of Cananéia showed distinct trends for sustainability and the study of the activity characteristics in each group allowed to observe such differences and identify aspects that determine them.

The social, technological and ethical dimensions showed more critical influence than the ecological and economic dimensions on sustainability trends of oyster extractivism in Cananéia.

The Mandira group showed the best performance in the sustainability assessment, due to advances promoted by local social organizations, externally supported by more than a decade. The Porto Cubatão group was placed at the opposite end of the sustainability assessment, because the group is very recent in the oysters extractivism activity.

The RAPFISH method proved to be a useful tool to provide data on the sustainability of different groups of extractivists studied.

\section{References}

ADRIANTO, L., MATSUDA, Y. and SAKUMA, Y., 2005. Assessing local sustainability of fisheries system: a multi-criteria participatory approach with the case of Yoron Island, Kagoshima prefecture, Japan. Marine Policy, vol. 29, no. 1, p. 9-23. http:// dx.doi.org/10.1016/j.marpol.2004.01.004.

ALDER, J., PITCHER, TJ., PREIKSHOT, D., KASCHNER, BJ. and FERRISS, B., 2000. How good is good?: a rapid appraisal technique for evaluation of the sustainability Status of fisheries of the north Atlantic. Fisheries Centre Research Reports, vol. 8, no. 2, p. 136-182.

BERKES, F., 2005a. Sistemas sociais, sistemas ecológicos e direitos de apropriação de recursos naturais. In VIEIRA, PF., BERKES, F. and SEIXAS, CS. (Eds.). Gestão Integrada e Participativa de recursos naturais: conceitos, métodos e experiências. Florianópolis: Secco. p. 47-72.

BERKES, F., 2005b. Commons theory for marine resource management in a complex world. In KISHIGAMI, N. and SAVELLE, JM. (Eds.). Indigenous use and management of marine resources. Osaka: National Museum of Ethnology. p. 13-31. Senri Ethnological Studies, no. 67.

BERKES, F., COLDING, J. and FOLKE, C. (Eds.), 2003, Navigating social-ecological systems: building resilience for complexity and change.Cambridge: Cambridge University Press. 393 p.

BERKES, F., MAHON, R., MCCONNEY, P., POLLNAC, RC. and POMEROY, RS., 2001. Managing small-sale fisheries: alternative directions and methods. Ottawa: International Development Research Centre. 285 p.

Brasil, 2002, Decreto de 13 de dezembro de 2002. Cria a Reserva Extrativista do Mandira, no Município de Cananéia, no Estado de São Paulo, e dá outras providências. Diário Oficial da União, Brasília, 16 dez.

CHARLES, AT., 2001. Beyond the status quo: rethinking fishery management. In PITCHER, T., HART, PJB. and PAULY, D. (Eds.). Reinventing fisheries management. Dordrecht: Editora Kluwer Academic Publishers. p. 101-122. 
FEENY, D., BERKES, F., MCCAY, BJ. and ACHESON, JM., 1990. The tragedy of the commons: twenty-two years later. Human Ecology, vol. 18, no. 1, p. 1-19. http://dx.doi.org/10.1007/ BF00889070. PMid:12316894

FOLKE, C., BERKES, F., COLDING, J., 1998. Ecological practices and social mechanisms for building resilience and sustainability. In BERKES, F. and FOLKE, C. (Eds.). Linking social and ecological systems: management practices and social mechanisms for building resilience. Cambridge: Cambridge University Press. 414 p.

GALVÃO, MSN., PEREIRA, OM., MACHADO, IC. and HENRIQUES, MB., 2000. Aspectos reprodutivos da ostra Crassostrea brasiliana (Lamarck, 1819) em manguezal do estuário de Cananéia, SP $\left(025^{\circ} \mathrm{S} ; 048^{\circ} \mathrm{W}\right)$.Boletim do Instituto de Pesca, vol. 26 , no. 2 , p. 147-162.

GARCIA, TR., 2005. Impactos da implantação de uma cooperativa de produção de ostras junto as comunidades extrativistas caiçaras no Litoral Sul/SP: um estudo de caso.Pirassununga: Universidade de São Paulo. 103 p. Masters Dissertation in Quality and Animal Productivity.

HENRIQUES, MB., CASARINI, LM., PEREIRA, OM. and MACHADO, IC., 2010. Estimativa da densidade do estoque da ostra de mangue, Crassostrea spp., na Reserva Extrativista do Mandira, Cananéia, SP, Brasil $\left(25^{\circ} \mathrm{S} ; 48^{\circ} \mathrm{W}\right)$.Arquivos de Ciências do Mar, vol. 46, no. 1, p. 5-11.

JANKOWISKY, M., 2007. Perspectivas a um manejo sustentável subsidiado pela ecologia humana: O caso da captura do caranguejouçá, Ucides cordatus, no Município de Cananéia - SP - Brasil. São Carlos: Universidade Federal de São Carlos. 92 p. Masters Dissertation in Ecology and Natural Resources.

LARKIN, PA., 1977. An epitaph for the concept of maximum sustained field.Transactions of the American Fisheries Society, vol. 106, no. 1, p. 1-11. http://dx.doi.org/10.1577/15488659(1977)106<1:AEFTCO $>2.0 . C O ; 2$.

MACHADO, IC., 2009. Um retrato do extrativismo: a sustentabilidade na exploração comercial da ostra de mangue em Cananéia-SP. São Carlos: Universidade Federal de São Carlos. 183 p. Doctoral Thesis in Ecology and Natural Resources.

MACHADO, IC., FAGUNDES, L. and HENRIQUES, MB., 2010. Perfil socioeconômico e produtivo dos extrativistas da ostra de mangue Crassostrea spp. em Cananéia, São Paulo, Brasil. Informações Econômicas, vol. 40, no. 7, p. 67-79.

MACHADO, IC., FAGUNDES, L. and HENRIQUES, MB., 2013. A comercialização da ostra de mangue em Cananéia, São Paulo, Brasil.Informações Econômicas. (In press).

MACHADO, IC., NORDI, N., HENRIQUES, MB., CARDOSO, T. and PEREIRA, OM., 2011. A integração da pesquisa ao conhecimento ecológico local no subsídio ao manejo: variações no estoque natural da ostra de mangue Crassostrea spp. Na Reserva Extrativista do Mandira, Cananéia-SP, Brasil.Ambiente \& Sociedade. Campinas, vol. 14, no. 1, p. 1-22.

MALDONADO, WTPV., 1999. Ordenamento da exploração da ostra do mangue no estuário de Cananéia-SP.São Paulo: Fundação Florestal/SMA-SP. 15 p. Technical Report.

MARRUL FILHO, S., 2001. Crise e sustentabilidade no uso dos recursos pesqueiros. Brasília, DF: Universidade de Brasília. 108 p. Masters Dissertation in Sustainable Development.
MEDEIROS, D., 2004. Lessons from the Equator initiative: Cananéia oyster producers' cooperative, Brazil. Winnipeg: IDRC/ UNDP/ Equator Initiative/ Centre for Community-Based Resource Management/ Natural Resources Institute/ University of Manitoba. 55 p. Technical Report.

MENDONÇA, JT. and MACHADO, IC., 2010. Mangrove oyster (Crassostrea spp.) (Sacco, 1897) extractivism in Cananéia estuary (São Paulo, Brazil) from 1999 to 2006: capture and management evaluation.Brazilian Journal of Biology = Revista Brasileira de Biologia, vol. 70, no. 1, p. 65-73. http://dx.doi.org/10.1590/ S1519-69842010000100010. PMid:20231961.

MENDONÇA, JT., 2007. Gestão dos recursos pesqueiros no Complexo Extuarino-Lagunar de Cananéia-Iguape-Ilha Comprida, Litoral Sul de São Paulo, Brasil. São Carlos: Universidade Federal de São Carlos. 388 p. Doctoral Thesis in Ecology.

OSTROM, E., GARDENER, R. and WALKER, JM., 1994. Rules, games and common-pool resources. Ann Arbor: University of Michigan. 377 p.

PEREIRA, OM., MACHADO, IC., HENRIQUES, MB. and YAMANAKA, N., 2001. Crescimento da ostra Crassostrea brasiliana semeada sobre tabuleiro em diferentes densidades na região estuarino- lagunar de Cananéia-SP $\left(25^{\circ} \mathrm{S}, 48^{\circ} \mathrm{W}\right)$. Boletim do Instituto de Pesca, vol. 27, no. 2, p. 163-174.

PEREIRA, OM., MACHADO, IC., HENRIQUES, MB., GALVÃO, MSN. and BASTOS, AA., 2000. Avaliação do estoque da ostra Crassostrea brasiliana (Lamarck, 1819) no manguezal da região estuarino-lagunar de Cananéia $\left(25^{\circ} \mathrm{S} ; 48^{\circ} \mathrm{W}\right)$. Boletim do Instituto de Pesca, vol. 26, no. 1, p. 49-62.

PITCHER, TJ. and PREIKSHOT, D., 2001. Rapfish: a rapid appraisal technique to evaluate the sustainability status of fisheries. Fisheries Research, vol. 49, no. 3, p. 255-270. http://dx.doi. org/10.1016/S0165-7836(00)00205-8.

PITCHER, TJ., 1999. Rapfish: a rapid appraisal technique for fisheries and its application to the code of conduct for responsible fisheries.FAO Fisheries Circular, no. 947, p. 1-47.

REBOUÇAS, GN., FILARDI, ACL. and VIEIRA, PF., 2006. Gestão integrada e participativa da pesca artesanal: potencialidades e obstáculos no litoral do estado de Santa Catarina.Ambiente e Sociedade, vol. 9, no. 2, p. 83-104. http://dx.doi.org/10.1590/ S1414-753X2006000200005.

SALAMONI, G. and GERARDI, LHO., 2001. Princícios sobre o ecodesenvolvimento e suas relações com a agricultura familiar. In GERARDI, LHO. and MENDES, IA. (Eds.). Teoria, técnica, espaços e atividades: temas da geografia contemporânea. Rio Claro: UNESP/ AGETEO. p. 73-96.

SANTOS, RR., MACHADO, I. and NORDI, N., 2009. Etnoconhecimento dos extrativistas da ostra de mangue (Crassostrea sp.) em Cananéia (São Paulo, Brasil). In Anais do $6^{\circ}$ Congresso de Meio Ambiente da AUGM, 2009. São Carlos. São Carlos: Universidade Federal de São Carlos. p. 1-15.

SEIXAS, CS. and BERKES, F., 2005, Mudanças sócio-ecológicas na gestão de recursos de uso comum: o caso da lagoa de Ibiraquera, SC. In VIEIRA, PF., BERKES, F. and SEIXAS, CS. (Eds.). Gestão Integrada e Participativa de Recursos Naturais .Florianópolis: Secco. p. 113-146

THÉ, APG. and NORDI, N., 2006. Common property resource system in a fishery of São Francisco River, Minas Gerais, Brazil. Human Ecology Review, vol. 3, no. 1, p. 10. 